\title{
ANALISIS DAMPAK LALU LINTAS DALAM MENCEGAH DAMPAK YANG DITIMBULKAN PADA PEMBANGUNAN PUSAT PERBELANJAAN DI KABUPATEN BANYUMAS DITINJAU DARI PERATURAN MENTERI PERHUBUNGAN NOMOR 75 TAHUN 2015 TENTANG PENYELENGGARAAN ANALISIS DAMPAK LALU LINTAS
}

Oleh: Danang Arif Rudhianto ${ }^{1}$

\begin{abstract}
The development of the shopping center business district is one of the factors dominant traffic impact. One of them is the development of the shopping center business area and Rita Hotel, although it is obliged to compose a reliable document in fact still cause traffic impact.

Type of doctrinal (normative) legal research, Perundangan-undangan approach method and conceptual approach.

Shopping and Hotel Rita according to regulation of the Minister of Transportation No. 75 year 2015, is as follows: a. Type of construction center and Hotel Rita is an activity in the form of buildings for trade and for hotels. $b$. The construction criteria of shopping centre and Hotel Rita include Andalalin mandatory (Article 3 paragraph (1)). c. Andalalin document drafting; Using consulting agencies who have experts and certified, comply with article 8 paragraph (2), and article 8 paragraph (3). d. Andalalin document substance.

Keywords: development, impact, shopping center.
\end{abstract}

\begin{abstract}
ABSTRAK
Pembangunan Kawasan Usaha Pusat Perbelanjaan menjadi salah satu faktor yang dominan terjadinya dampak lalu lintas. Salah satunya adalah pembangunan kawasan Usaha Pusat Perbelanjaan dan Hotel Rita, walaupun sudah diwajibkan menyusun dokumen andalalin pada kenyataannya masih menimbulkan dampak lalu lintas.

Tipe penelitian hukum Doktrinal (Normatif), metode pendekatan Perundanganundangan dan Pendekatan Konseptual.

Perbelanjaan dan Hotel Rita Menurut Peraturan Menteri Perhubungan Nomor 75 Tahun 2015, adalah sebagai berikut: a. Jenis Pembangunan Pusat Perbelanjaan dan Hotel Rita adalah kegiatan berupa bangunan untuk Perdagangan dan untuk hotel. b. Kriteria Pembangunan Pusat Perbelanjaan dan Hotel Rita termasuk wajib dilakukan Andalalin. (Pasal 3 ayat (1)). c. Penyusun Dokumen Andalalin; menggunakan lembaga konsultan yang memiliki tenaga ahli dan bersertifikat, memenuhi Pasal 8 Ayat (2), dan Pasal 8 ayat (3). d. Substansi Dokumen Andalalin.

Kata Kunci: pembangunan, dampak, pusat perbelanjaa
\end{abstract}

\footnotetext{
${ }^{1}$ Pegawai PNS Pemda Banyumas
} 


\section{A. Pendahuluan}

Beberapa Wilayah di Kabupaten Banyumas sebagai pusat perdagangan, jasa, pendidikan, pemukiman, dan pariwisata mengalami perkembangan yang pesat dan kompetitif. Seiring pesatnya pembangunan suatu kawasan

dan/atau lokasi tertentu yang merupakan bagian dari sistem transportasi, akan menimbulkan potensi adanya perjalanan tambahan pada saat proses pembangunan sehingga mempunyai pengaruh atau dampak terhadap kondisi lalu lintas disekitarnya.

Menunjuk beberapa tempat atau titik kemacetan di wilayah Kota Purwokerto, dapat dilihat bahwa Pembangunan Kawasan Usaha Pusat Perbelanjaan menjadi salah satu faktor yang dominan terjadinya dampak lalu lintas. Salah satunya adalah pembangunan kawasan Usaha Pusat Perbelanjaan dan Hotel Rita, walaupun sudah diwajibkan menyusun dokumen andalalin pada kenyataannya masih menimbulkan dampak lalu lintas.

Sebagaimana penelitian objek sejenis yang telah dilakukan, kali ini penulis coba maneliti dari aspek hukumnya, bahwa setelah diwajibkan dokumen ANDALALIN ternyata penyelenggaraan ANDALALIN di beberapa wilayah Kabupaten Banyumas masih belum dapat memenuhi tujuan penyelenggaraannya.

\section{B. Metode Penelitian}

Tipe penelitian hukum Doktrinal (Normatif), metode pendekatan Perundangan-undangan dan Pendekatan Konseptual, sumber data yang digunakan adalah data sekunder. Jenis bahan hukum yang dipergunakan adalah bahan hukum primer dan bahan hukum sekunder.

C. Hasil Penelitian dan

\section{Pembahasan}

Penulis menggunakan beberapa teori sebagai berikut:

\section{Teori Negara Hukum}

Teori Negara hukum di pelopori oleh Imanuel Kant dan Hans Kelsen, negara pada prinsipnya tidak berdasarkan kekuasaan belaka (machtsstaat), tapi harus berdasarkan hukum (rechtsstaat). ${ }^{2}$ Munculnya konsep rechtsstaat dari Freidrich Julius Stahl, diilhami oleh pemikiran Immanuel Kant. Menurut Stahl, unsur-unsur negara hukum (rechtsstaat) adalah: ${ }^{3}$
a. Perlindungan hak-hak asasi manusia
b. Pemisahan atau

\footnotetext{
2 Hans kelsen, General Theory of Law and State, (translated) Anders wedberg, Russel \& Russell, New York, 1973, lihat Theo Huijbers, Filsafat Hukum, hal. 156-161

3 Ridwan. HR, Hukum Administrasi Negara (Edisi Revisi), Raja Grafindo Persada. Jakarta, 2011 hlm.2
} 
rnal Idea Hukum

Vol. $6 \mathrm{No} .1 \mathrm{Maret} 2020$

Magister Hukum Universitas Jenderal Soedirman

pembagian kekuasaan

untuk menjamin hak-hak

itu.

c. Pemerintahan

berdasarkan peraturan

perundang-undangan;

dan

d. Peradilan administrasi

dalam perselisihan.

\section{Teori Negara Hukum \\ Demokratis}

Dalam sistem demokrasi, penyelenggaraan negara itu harus bertumpu pada partisipasi dan kepentingan rakyat. Hubungan antara negara hukum dan demokrasi tidak dapat dipisahkan. Demokrasi tanpa pengetahuan hukum akan kehilangan bentuk dan arah, sedangkan hukum tanpa demokrasi akan kehilangan makna. Demokrasi merupakan cara paling aman untuk mempertahankan kontrol atas negara hukum. Dengan demikian, negara hukum yang bertopang pada sistem demokrasi, sebagai perkembangan lebih lanjut dari demokrasi konstitusional. ${ }^{4}$

\section{Hukum Administrasi Negara}

Utrecht menyebutkan bahwa hukum administrasi negara adalah hukum yang mengatur sebagian lapangan pekerjaan

\footnotetext{
${ }^{4}$ Ridwan, HR., Hukum Administrasi Negara,
} UII Press, Yogyakarta 1988, hlm., 6. administrasi negara. ${ }^{5}$ Hukum administrasi negara terkandung dua aspek, yaitu:

1. Aturan-aturan hukum yang mengatur dengan cara bagaimana alat-alat perlengkapan negara itu melakukan tugasnya.

2. Aturan-aturan hukum yang mengatur hubungan hukum antara perlengkapan administrasi negara atau pemerintah dengan para warga negaranya. $^{6}$

Hukum administrasi negara adalah hukum dan peraturan-peraturan yang berkenaan dengan pemerintah dalam arti sempit atau administrasi negara, peraturan-peraturan tersebut dibentuk oleh lembaga legislative untuk mengatur tindakan pemerintah dalam hubungannya dengan warga negara, dan sebagian peraturan- peraturan itu dibentuk pula oleh administrasi negara. $^{7}$

\footnotetext{
${ }^{5}$ E. Utrecht, Pengantar Hukum Administrasi Negara Indonesia, Bina IImu, Surabaya, 1988, hlm. 8

Soehino, Asas-asas Hukum Tata Pemerintahan, Liberty, Yogyakarta, 1984, hlm. 2

7 Ridwan, HR. Hukum Administrasi Negara, UII Press, Yogyakarta., hlm. 2627. Dalam hal ini mengutip AM. Donner ketika ia mengatakan bahwa sebagian besar hukum administrasi negara dibentuk oleh pembuat Undang-Undang dan/atau Hakim untuk mengatur Pemerintahan
} 


\section{Teori llmu Perundang- undangan}

Teori jenjang hukum (Stufentheorie) yang dikemukakan oleh Hans Kelsen, Menyebutkan bahwa norma-norma hukum itu berjenjang-jenjang dan berlapislapis dalam suatu hierarki (tata susunan) dalam arti suatu norma yang lebih tinggi berlaku, bersumber dan berdasar pada norma yang lebih tinggi lagi, demikian seterusnya sampai pada suatu norma yang tidak dapat ditelusuri lebih lanjut dan bersifat hipotetis dan fiktif, yaitu Norma Dasar (Grundnorm). Norma Dasar merupakan norma tertinggi dalam suatu sistem norma tersebut tidak lagi dibentuk oleh suatu norma yang lebih tinggi lagi, tetapi Norma Dasar itu ditetapkan terlebih dahulu oleh masyarakat sebagai Norma Dasar yang merupakan gantungan bagi norma-norma yang berada di bawahnya, sehingga suatu Norma Dasar itu dikatakan pre-supposed..$^{8}$

\section{Teori Analisis Dampak Lalu} Lintas

\section{Dalam Peraturan Menteri}

(bestruursrecht is het recht dat volgens wetgever en/of rechter specifiek voor het bestuur geld)

8 Maria Farida Indrati Soeprapto, IImu Perundang-Undangan : Jenis, Fungsi, dan Materi Muatan, Kanisius, Yogyakarta, 2010, halaman 41.
Perhubungan Nomor 75 Tahun 2015 disebutkan bahwa Analisis Dampak Lalu Lintas adalah serangkaian kegiatan kajian mengenai dampak lalu lintas dari pembangunan pusat kegiatan, pemukiman, dan infrastruktur yang hasilnya dituangkan dalam bentuk dokumen hasil analisis dampak Ialu lintas.

Regidor dan Teodoro (2003) menyebutkan Andalalin merupakan upaya yang relevan terhadap pencarian para perencana maupun insinyur dalam meminimalisasi, jika tidak menyelesaikan secara total, masalah yang menyangkut kemacetan lalu lintas di kota yang berkembang. ${ }^{9}$

Dikun dan Arif (1993) mendefinisikan analisis dampak lalu-lintas sebagai suatu studi khusus dari dibangunnya suatu fasilitas gedung dan penggunaan lahan lainnya terhadap sistem transportasi kota, khususnya jaringan jalan di sekitar lokasi gedung. Menurut Tamim, Analisa dampak lalu lintas pada dasarnya merupakan analisis pengaruh pengembangan tata guna lahan

9 Sukma Larastiti-Budi Yulianto, Kinerja Analisis Dampak Lalu Lintas (Andalalin) Di Kota

Surakarta, The $18^{\text {th }}$ FSTPT International Symposium, Unila, Bandar Lampung, August 28, 2015 


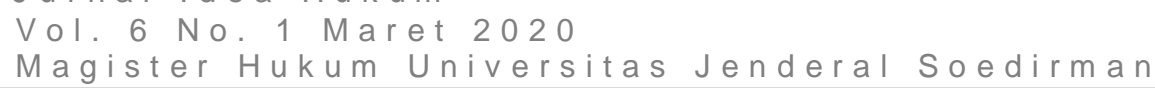

terhadap sistem pergerakan arus lalu-lintas disekitarnya yang diakibatkan oleh bangkitan lalu lintas yang baru, lalu lintas yang beralih, dan oleh kendaraan keluar masuk dari/bahan tersebut juga menyebutkan bahwa bangkitan perjalanan, merupakan tahapan pemodelan yang memperkirakan jumlah pergerakan yang tertarik dari suatu zona atau tata guna lahan. ${ }^{10}$

\section{A. Penyelenggaraan Andalalin Pembangunan Pusat Perbelanjaan dan Hotel} Rita.

Penelitian penyelenggaraan Andalalin pada Dokumen Andalalin

Pembangunan Pusat Perbelanjaan dan Hotel Rita hasilnya sebagai berikut:

1. Pendahuluan

a. Undang-Undang Republik Indonesia No. 22 Tahun 2009 TentangLalu Lintas dan Angkutan Jalan.

\footnotetext{
${ }^{10}$ Arief Subechi Widodo. Analisis Dampak Lalu Lintas (Andalalin) Pada Pusat Perbelanjaan yang telah Beroperasi Ditinjau dari Tarikan Perjkalanan (Studi Kasus Pada Pacific Mall Tegal), Tesisi Program Magister Teknik Sipil Jurusan Manajemen Rekayasa Infrastruktur, Program Pasca Sarjana Universitas Diponegoro Semarang 2007, hal 6
}

b. Undang-Undang Republik Indonesia No. 26 Tahun 2007 Tentang Penataan Ruang.

c. Undang-Undang Republik Indonesia No. 38 Tahun 2004 Tentang Jalan.

d. Peraturan Pemerintah No. 32 Tahun 2011 Tentang Manajemen dan Rekayasa, Analisis Dampak serta Manajemen Kebutuhan Lalu Lintas.

e. Peraturan Menteri Perhubungan No. 14 Tahun 2006 Tentang Manajemen dan Rekayasa Lalu Lintas di jalan.

2. Metodologi dapat dijabarkan sebagai berikut:

1. Lokasi Penelitian Studi ANDALALIN dilaksanakan di Kota Purwokerto, pada jaringan Jalan Jenderal Soedirman, Jalan Masjid, dan jalan Slamet Riyadi.

2. Alat Penelitian; Peralatan yang digunakan dalam penelitian ini adalah: Formulir Survai, papan survai, alat tulis dan alat bantu lainnya, Counter, Jam dan Stop Watch, Walking Measure, Kamera Video dan Komputer.

3. Survai manajemen lalu lintas kondisi eksisting disesuaikan dengan kebutuhan data untuk dianalisis lalu lintas dan angkutan jalan saat itu.

4. Survai Kecepatan Perjalanan di ruas Jalan Jenderal 
Soedirman dengan mengukur

secara manual waktu

tempuh kendaraan ringan

untuk melintasi dua titik sejauh $100 \mathrm{~m}$.

5. Analisis Kinerja Ruas Jalan dan Simpang; dipakai Volume lalu lintas dua arah pada jam paling sibuk dalam sehari untuk dasar analisa unjuk kinerja ruas jalan dan persimpangan.

6. Kondisi Rona Lingkungan dan Rencana Kegiatan;

Pembangunan Pusat

Perbelanjaan dan Hotel Rita direncanakan dibangun dengan 18 (delapan belas) lantai yang terdiri dari Pusat Perbelanjaan, Hotel, Bioskop, Foodcourt, dan dilengkapi dengan fasilitas penunjang lainnya. Masingmasing lantai diperuntukan untuk kegiatan pertokoan (lantai 1-5), bioskop (lantai 3), kantin dan parkir (basement 1 dan 2), Mushola (lantai 2-4), serta hotel (lantai 6-14).

7. Analisis Dampak; Pelaksanaan analisis berpedoman pada Peraturan Pemerintah No. 32 Tahun $2011 \quad$ Tentang Manajemen dan Rekayasa, Analisis Dampak serta Manajemen Kebutuhan Lalu Lintas.

8. Prediksi Dampak Lalu Lintas
9. Upaya Penanganan Dampa

\section{B. Hambatan Yang Muncul Dalam Penyelenggaraan Andalalin}

1. Hambatan Normatif; Pengaturan Andalalin di daerah belum baku Amda maupun dokumen lingkungan lainnya seperti UPL/UKL, Andalalin pada awalnya dipandang sebagai bagian dari Analisis Dampak Lingkungan.

2. Hambatan Kelembagaan

a. Masih ada lembaga yang menganggap bahwa Andalalin tidak diperlukan karena sudah ada dokumen Amdal dan UPL/UKL.

b. Koordinasi antar lembaga terkait masih sulit, dikarenakan penunjukan pegawai sebagai Anggota bukan bidangnya.

c. Kurang koordinasi antar Lembaga yang menerbitkan ljin.

d. Pengawasan oleh lembaga lembaga terkait kurang maksimal.

e. Penegakan oleh lembaga yang berwenang kurang tegas.

3. Hambatan Sumber Daya Manusia (SDM); Minimnya Tenaga ahli lembaga konsultan 
rnal Idea Hukum

Vol. 6 No. 1 Maret 2020

Magister Hukum Universitas Jenderal Soedirman

Andalalin yang memiliki sertifikat.

nasional;

4. Analisis distribusi perjalanan;

C. Pembahasan Hasil Analisis

5. Analisis pemilihan moda

6. Analisis perjalanan;

Dampak Lalu Lintas pada pembangunan Pusat Perbelanjaan

dan Hotel Rita Menurut Peraturan

Menteri Perhubungan Nomor 75

Tahun 2015, adalah sebagai berikut:

a. Jenis Pembangunan Pusat Perbelanjaan dan Hotel Rita adalah kegiatan berupa bangunan untuk Perdagangan dan untuk hotel,

b. Kriteria Pembangunan Pusat Perbelanjaan dan Hotel Rita termasuk wajib dilakukan Andalalin. (Pasal 3 ayat (1))

c. Penyusun Dokumen Andalalin; menggunakan lembaga konsultan yang memiliki tenaga ahli dan bersertifikat, memenuhi Pasal 8 Ayat (2), dan Pasal 8 ayat (3).

d. Substansi Dokumen Andalalin Dokumen hasil Andalalin telah memuat hal-hal sebagaimana diatur dalam ketentuan Pasal 9 Ayat (2) sebagai berikut:

1. Perencanaan dan metodologi analisis dampak lalu lintas,

2. Analisis kondisi lalu lintas dan angkutan jalan saat ini

3. Analisis Bangkitan/Tarikan Lalu Lintas dan Angkutan Jalan akibat pembangunan berdasarkan kaidah teknis transportasi dengan menggunakan faktor trip rate yang ditetapkan secara

7. Simulasi kinerja lalu lintas yang dilakukan terhadap analisis dampak lalu lintas

8. Rekomendasi dan rencana implementasi penanganan dampak

9. Rincian tanggung jawab Pemerintah dan Pengembang atau Pembangun dalam penanganan dampak berupa kegiatan.

10. Rencana pemantauan dan evaluasi yang namun tidak di sajikan

11. Gambaran umum lokasi yang akan dibangun atau dikembangkan, setelah dicermati ada beberapa hal yang tidak memenuhi ketentuan Pasal 9 (Ayat (2) huruf k), bahwa gambaran umum lokasi yang akan dibangun atau dikembangkan, meliputi ;

a. Kesesuaian dengan rencana tata ruang wilayah, Pembangunan Pusat Perbelanjaan dan Hotel Rita telah sesuai Tata Ruang Wilayah. Apabila mengacu pada Perda No 10 Tahun 2011 Tentang Rencana Tata Ruang Wilayah Kabupaten Banyumas Tahun 2011-2031 dan Perda Nomor 6 Tahun 2002 Tentang Rencana Detail Tata Ruang Kota (RDTRK) Purwokerto yang sudah tidak berlaku, maka lokasi yang dimohonkan untuk Pembangunan Pusat Perbelanjaan dan Hotel 


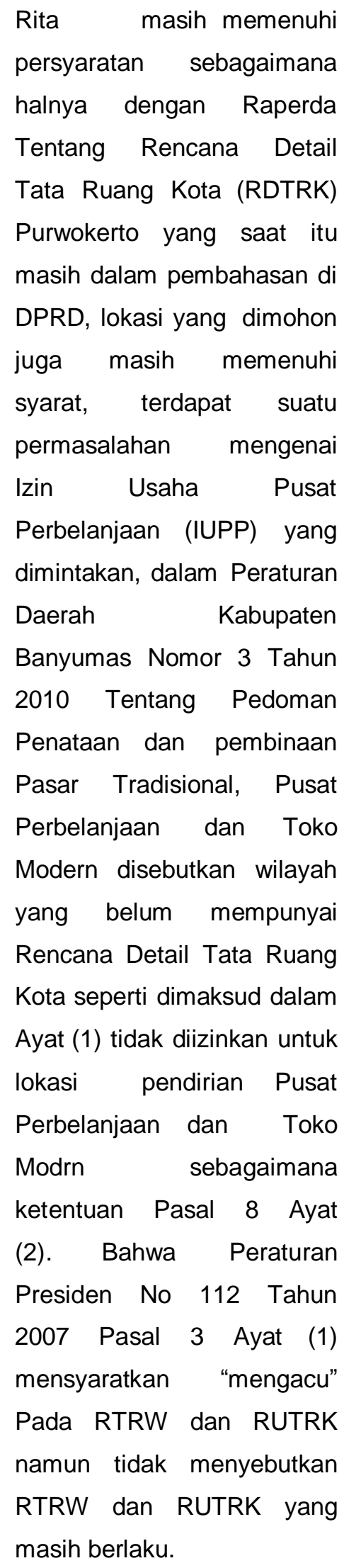

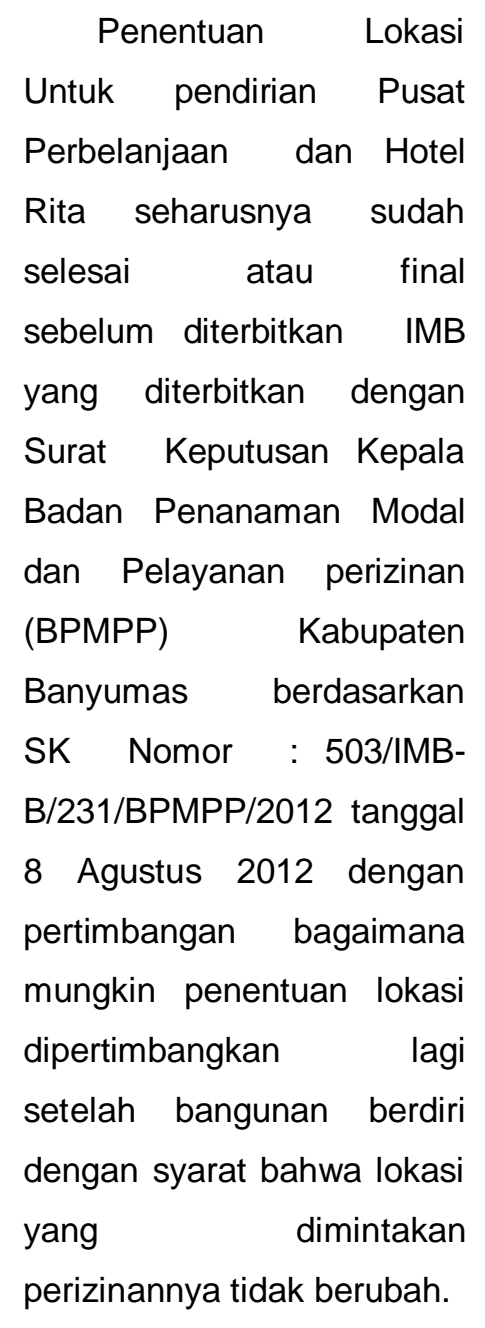

2. Peta lokasi yang memuat tentang jenis bangunan, rencana pembangunan baru atau pengembangan.

3. Kondisi fisik sarana dan prasarana lalu lintas dan angkutan jalan di sekitar lokasi rencana pembangunan baru atau pengembangan.

4. Kondisi sosial ekonomi di sekitar lokasi rencana pembangunan baru atau pengembangan; dan

5. Kondisi lalu lintas dan pelayanan angkutan jalan yang ada di sekitar lokasi rencana 
urnal Idea Hukum

Vol. $6 \mathrm{No} .1 \mathrm{Maret} 2020$

Magister Hukum Universitas Jenderal Soedirman

pembangunan baru atau

mendasar pada struktur, pengembangan.

luasan, atau fungsi

e. Proses Penilaian Andalalin

bangunan Pusat

Proses Penilaian Dokumen

Perbelanjaan dan Hotel

Andalalin adalah sebagai berikut:

Rita, yang menyebabkan

1) Analisis Dampak Lalu Lintas perubahan Pola bangkitan Pembangunan Pusat Perbelanjaan dan Hotel Rita, telah disetujui oleh bupati dengan bukti diterbitkannya surat Persetujuan Nomor $551.1 / 1817 / 2012$ tanggal 18 Oktober 2012 (Pasal 11 Ayat (1)), dengan kewajiban pengembang sebagai berikut:

a Melaksanakan hasil kajian Andalalin dikawasan lokasi pembangunan

sebagaimana tersebut dalam Dokumen Andalalin.

b Pengembang atau pengelola berkewajiban menyediakan dan memasang fasilitas keselamatan serta bangunan pendukung yang telah disepakati bersama sebagaimana tertuang dalam surat pernyataan kesanggupan.

c Pengembang atau pengelola wajib mengkaji dan merevisi dokumen Andalalin apabila dikemudian hari terjadi perubahan dan/atau pengembangan yang dan tarikan lalu lintas di kawasan Pusat

Perbelanjaan dan Hotel Rita.

2) ljin Lokasi, Izin mendirikan bangunan (IMB) Pusat Perbelanjaan dan Hotel Rita pada saat proses penyusunan dokumen Andalalin sudah dikeluarkan, hal ini tidak dibenarkan karena Hasil Andalalin sebagaimana dimaksud merupakan salah satu persyaratan Pengembang atau Pembangun untuk memperoleh ljin Lokasi, ljin Mendirikan Bangunan, ljin pembangunan bangunan gedung dengan fungsi khusus sesuai dengan ketentuan peraturan perundangundangan di bidang bangunan gedung (Pasal 12)

3) Untuk memperoleh ijin lokasi dan IMB Pengembang atau Pembangun harus menyampaikan dokumen hasil Andalalin.

4) Pemberian persetujuan 
dokumen Andalalin setelah dilakukan penilaian. Pada awalnya Dokumen Hasil Andalalin belum disetuju, dokumen dikembalikan untuk disempurnakan, selanjutnya pengembang atau Pembangun menyempurnakan Dokumen Hasil Andalalin dengan rekomendasi Tim Evaluasi. Setelah Andalalin dinyatakan memenuhi persyaratan, Pengembang atau Pembangun diminta membuat dan menandatangani surat pernyataan kesanggupan melaksanakan semua kewajiban di dalam dokumen hasil Andalalin.

f. Tindak lanjut hasil Analisis

Dampak Lalu Lintas

Berdasarkan pengamatan setelah dokumen hasil Andalalin diterima, ada beberapa Rekomendasi Andalalin yang tidak dilaksanakan, sehingga dikenai sanksi administratif oleh pemberi izin sesuai dengan ketentuan peraturan perundang-undangan. (Pasal 17 Ayat (1). Sanksi administratif berupa peringatan tertulis dikenai sebanyak 3 (tiga) kali dengan jangka waktu masing-masing 30 (tiga puluh) hari kalender (Pasal 19 Ayat (2)). Dalam hal Pengembang atau Pembangun tidak melaksanakan kewajiban setelah berakhirnya jangka waktu peringatan tertulis ke 3 (tiga), dikenai sanksi administratif berupa penghentian sementara pelayanan urnum dan/atau penghentian sementara kegiatan selama 30 (tiga puluh) hari kalender, selanjutnya jika tetap tidak melaksanakan kewajiban setelah berakhirnya jangka waktu sebagaimana dimaksud, dikenai denda paling banyak $1 \%$ (satu per seratus) dari nilai kewajiban yang harus dipenuhi oleh pengembang atau pembangun, dalam waktu 10 (sepuluh) hari kalender sejak tanggal pengenaan sanksi denda administratif atau 90 (sembilan puluh) hari kalender sejak pembayaran denda, Pengembang atau Pembangun tidak melaksanakan kewajibannya, dikenai sanksi pembatalan atau pencabutan izin. Dalam hal ini Pemerintah Daerah Kabupaten Banyumas menggunakan mekanisme Denda Administrasi.

D. Penutup

1. Kesimpulan

a. Penyusunan dokumen Andalalin belum menggunakan Format yang baku menurut Peraturan Menteri Perhubungan Republik Indonesia Nomor PM 75 Tahun 2015 Tentang Penyelenggaraan Analisis 
141 | Jurna I I dea Hukum

Vol. 6 No. 1 Maret 2020

Magister Hukum Universitas Jenderal Soedirman

Dampak Lalu Lintas.

Pembangun Pusat

b. Pembangunan Pusat

Perbelanjaan dan Hotel Rita

telah sesuai dengan Perda

Banyumas Nomor 10 Tahun

2011 Tentang Rencana Tata

Ruang Wilayah Kabupaten

Banyumas Tahun 2011-

2031. Apabila mengacu

pada Perda No 10 Tahun

2011 Tentang Rencana Tata

Ruang Wilayah Kabupaten

Banyumas Tahun 2011-

2031 dan Perda Nomor 6

Tahun 2002 Tentang

Rencana Detail Tata Ruang

Kota (RDTRK) Purwokerto

yang sudah tidak berlaku

lagi.

c. Penyelenggaraan Andalalin pada Pembangunan Pusat Perbelanjaan dan Hotel Rita tidak sesuai dengan ketentuan tentang penyelenggaraan Andalalin,

d. Hasil Analisis Dampak Lalu Lintas Pembangunan Pusat Perbelanjaan dan Hotel Rita, telah disetujui oleh bupati dengan bukti diterbitkannya surat Persetujuan Analisis Dampak Lalu Lintas Pembangunan Pusat Perbelanjaan dan Hotel Rita Nomor $\quad 551.1 / 1817 / 2012$ tanggal 18 Oktober 2012.

e. Pengembang atau

Perbelanjaan dan Hotel

Rita Tidak melaksanakan

beberapa kewajiban yang

melekat Bersama surat persetujuan Andalalin.

f. Pemerintah

Daerah

Kabupaten Banyumas

belum melaksanakan

tindakan penegakan

peraturan terhadap

pelanggaran yang dilakukan

Pengembang

g. Penyelenggaran Andalalin

Pusat Perbelanjaan dan

Hotel Rita belum efektif

mencegah Dampak Yang

Ditimbulkan Pada

Pembangunan Pusat

Perbelanjaan dan Hotel Rita

Purwokerto Kabupaten

Banyumas

2. Saran

a. Dalam penyelenggaraan Analisis Dampak Lalu Lintas (ANDALALIN) Untuk memudahkan penyusunan dan penilaian dokumen ANDALALIN harus ditetapkan Format yang baku sebagai pedoman penyusunannya.

b. Dalam hal permohonan persetujuan dokumen ANDALALIN yang baru, pihak Dinas Perhubungan Kabupaten Baanyumas harus melakukan koordinasi 
dengan Badan Penamaman

Modal Perizinan Pelayanan

Terpadu Satu Pintu (BPMPPTSP) dan sebaliknya.

c. Memasukan

Dokumen

ANDALALIN ke dalam sistem permohonan IMB

secara Online sebagai komponen Syarat untuk permohonan IMB, sehingga proses permohonan IMB tidak bisa dilayani sebelum Dokumen ANDALALIN disetujui.

d. Dalan hal penentuan lokasi, agar dapat dipastikan sesuai dengan Rencana Tata Ruang Wilayah, Penyusunan Dokumen ANDALALIN pada Gambaran umum, lokasi yang akan dibangun dimintakan atau ditetapkan menyertakan Advice Planing sebagai pintu masuk Persetujuan dokumen ANDALALIN.

Sebelum yang $\quad$ berwenang
memberikan persetujuan Dokumen
ANDALALIN, $\quad$ Tim Evaluasi
ANDALALIN harus elakukan hal-hal
sebagai berikut:

1. memastikan bahwa rekomendasi akan dilaksanakan.

2. Pengawasan terhadap pelaksanaan kewajiban yang tercantum dalam dokumen
ANDALALIN lebih ketat.

3. Memberikan sanksi lebih tegas, Pembatalan izin dan/atau pencabutan izin pada pembangun yang melanggar kewajiban.

4. Penyelenggaraan Dokumen ANDALALIN jangan sebagai formalitas belaka.

5. Ada harmonisasi peraturan yang mengatur Perizinan, ANDALALIN dengan peraturan terkait lainnya.

\section{DAFTAR PUSTAKA}

Sukma Larastiti-Budi Yulianto, Kinerja Analisis Dampak Lalu Lintas (Andalalin) Di Kota

Surakarta, The $18^{\text {th }}$ FSTPT International Symposium, Unila, Bandar Lampung, August 28, 2015

Arief Subechi Widodo. Analisis Dampak Lalu Lintas (Andalalin) Pada Pusat Perbelanjaan yang telah Beroperasi Ditinjau dari Tarikan Perjkalanan (Studi Kasus Pada Pacific Mall Tegal), Tesisi Program Magister Teknik Sipil Jurusan Manajemen Rekayasa Infrastruktur, Program Pasca Sarjana Universitas Diponegoro Semarang 2007.

Ridwan, HR., Hukum Administrasi Negara , UII Press, Yogyakarta 1988.

E. Utrecht, Pengantar Hukum Administrasi Negara Indonesia, Bina IImu, Surabaya, 1988.

Soehino, Asas-asas Hukum Tata Pemerintahan, Liberty, Yogyakarta, 1984.

Ridwan, HR. Hukum Administrasi Negara, UII Press, Yogyakarta.

Maria Farida Indrati Soeprapto, IImu Perundang-Undangan : Jenis, Fungsi, dan Materi Muatan, Kanisius, Yogyakarta, 2010. 
143 | Jurna I I d e a Hukum

Vol. 6 No. 1 Maret 2020

Magister Hukum Universitas Jenderal Soedirman

Hans kelsen, General Theory of Law and State, (translated) Anders wedberg,Russel \& Russell, New York, 1973, lihat Theo Huijbers, Filsafat Hukum.

Ridwan. HR, Hukum Administrasi

Negara (Edisi Revisi), Raja

Grafindo Persada. Jakarta, 2011. 